\title{
The Practice of US Execution of Juvenile Delinquents in Dated Times Vis-À-Vis International Human Rights Laws and Case Laws
}

\author{
Nuruye Beyan Feleke \\ School of Law, Samara University, Samara, Ethiopia \\ Email: nuruye@gmail.com
}

Received 12 October 2015; accepted 28 December 2015; published 31 December 2015

Copyright (C) 2015 by author and Scientific Research Publishing Inc.

This work is licensed under the Creative Commons Attribution International License (CC BY). http://creativecommons.org/licenses/by/4.0/

(c) (i) Open Access

\section{Abstract}

The prohibition against the death penalty as applied to juveniles is widely practiced across the globe. The United Nations treaties have prescribed age requirements for extreme sentences such as the juvenile death penalty. Despite these requirements very few countries continue to sentence juveniles to the death penalty that ignore the age of the offender. The United States leads the world in state-sanctioned juvenile executions. However, recently the United States came into compliance with international norms and heralded a major shift by banning the death penalty as applied to juveniles in the Supreme Court case of Roper v. Simmons in 2005. Due to that, the overwhelming majority of states do not sentence juveniles to the death penalty and the prohibition against sentencing children to die has become accepted. On the contrary, for over three centuries, the United States executed juvenile delinquents and the Supreme Court, for a long time, held there was no national consensus rejecting juvenile executions and not a violation of the Eighth Amendment. The US is already a party to a number of fundamental human rights treaties that impact capital punishment. To some extent, the US has isolated itself from the most direct effects of these treaties through reservations or by invoking domestic law. But the US is committed to the underlying human rights principles of these treaties and these instruments can serve as a starting point for reforming and restricting the death penalty from a human rights perspective.

\section{Keywords}

Juvenile, Prohibition, Delinquents, Execution 


\section{Introduction}

The concept of having a separate legal framework for juvenile offenders is relatively new. Throughout history, children were accused of wrongdoing were imprisoned with adults. In the early nineteenth century, the idea of reforming youth offenders took root in the United States.

The American juvenile justice system has developed over the past century with a number of differences that distinguish it from the adult criminal justice process. Juvenile justice advocates supported the differences on diminished youthful offender accountability and legal understanding, and youths' greater amenability to treatment. The first juvenile court was established in Chicago, Illinois, in 1899; yet a century later there is still considerable debate over the goals and the legal procedures for dealing with juvenile offenders. The question of whether juvenile offenders should be tried and sentenced differently than adult offenders elicits strongly held opinions from citizens, policy makers, and professionals. Taking in to consideration this approach, the writer examines it in lights of major international human rights law and recent jurisprudence, in doing so the paper encompasses three sections.

The first section summarizes the historical development of juvenile justice and juvenile delinquency in US Section II examines the US execution of juvenile delinquents in dated times in the context of major international human rights laws and in relation to customary international law and the doctrine of jus cogens. Section III reviews the Eighth Amendment of US constitution and the recent Supreme Court decision and plurality opinions on the subject of juvenile death penalty. Finally, the paper concludes that the practice of US execution of juvenile delinquents was/is against international human rights treaties, customary international law and the doctrine of jus cognes.

\section{A Brief Historical Overview of Juvenile Justice and Juvenile Delinquency}

\section{Historical Background of Execution of Juvenile Delinquents in US}

In the early twentieth century, prior to the advent of the formal juvenile system, the same criminal justice system was used for both children and adults (Arnett, 1988). Due to the belief in its effect as a deterrent, the death penalty was historically applied with little, if any, distinction as to the age of the criminal (Koestler, 1957). For example, in 1338 England, a ten year old boy who killed his companion and concealed the body was sentenced to death (Platt \& Diamond, 1966). The judge reasoned that since the boy had concealed the body, he could distinguish between good and evil and therefore should be put to death for his crime. Various courts over time had used differing terminology in their attempt to measure a child's culpability, including the following: having a guilty knowledge, fully aware of the nature and consequences of the act, plainly showed intelligent malice, and mentally capable of distinguishing between right and wrong (Miles v. State, 54) During the $19^{\text {th }}$ century, a number of developments paved the way for a separate system of justice for juveniles in the United States (Lawrence, 1998).

A juvenile justice system separate from the adult criminal justice system was established in the United States in Cook County, Illinois 1899, the first such court in the world (Harvard University, 2005) Aprimary purpose of the juvenile justice system was to hold juvenile offenders accountable for delinquent acts while providing treatment, rehabilitative services, and programs designed to prevent future involvement in law-violating behavior (Cothern, 2003). The goal envisioned was to divert young offenders from the destructive punishments of criminal courts and encourages rehabilitation based on the individual' needs (Streib, 2004). The effort recognized that children are different than adults in terms of cognitive development, impulse and emotional control, and judgment capability. The early juvenile courts were based on the legal doctrine of parenspatriae (a Latin term that means "parent of the country"), which justified the court's jurisdiction in cases in which parents had failed to properly care for and supervise their children (Tuell, 1998).

Under common law, throughout the late 18th century, "infants" below the age of seven were presumed to be incapable of criminal intent and were, therefore, exempt from prosecution and punishment, while a child between the ages of seven and fourteen was presumed to lack criminal capacity, a presumption only infrequently rebutted (Snyder \& Sickmund, 2006). In other words, if the government successfully rebutted this presumption, juvenile offenders above the age of seven could be sentenced and executed as if they had achieved the age of majority. Children above the age of fourteen bore full criminal responsibility, although punishment could always be mitigated. 
The first documented United States execution of a juvenile offender occurred in 1642, when sixteen years old Thomas Graunger was put to death in Plymouth Colony, Massachusetts. Prior to 1642, colonial America's favored punishment for juvenile offenders was to have parents "beat the devil" out of their child if he or she committed acrime (Spring, 1998). Parents could be required to publicly execute, whip, or even banish their children if the community found them to be criminally liable.

Although rehabilitation was the original objective of juvenile courts, the increasingly violent and destructive behavior associated with juvenile delinquency over the last several decades has thwarted the realization of this goal (Yeckel, 1997). The failure of traditional juvenile justice systems to adequately rehabilitate violent juvenile offenders has prompted many states to modify their juvenile codes to remove violent juveniles from the protective jurisdiction of the juvenile courts (Torbet et al., 1996).

The United States leads the world in state-sanctioned juvenile executions. This indicates a shift away from the historical purposes of the separate juvenile justice system and a contrary to the research-supported understanding that adolescence is a transitional period, when cognitive abilities, emotions, judgment, impulse control, identity, and the brain are still developing, and are developing in the context of families, kinship systems, and communities. In the three and a half centuries since the first execution of a juvenile offender in the United States, three hundred sixty five Americans have been executed for crimes committed as juveniles (Banks, 1999).

\section{Prohibition of Juvenile Death Penalty under International Human Rights Laws}

Several significant human rights laws expressly prohibit the execution of juveniles and restrict the rights of states to derogate from these provisions. These multilateral agreements urge states to exclude minors from the death penalty not because of international disapproval of capital punishment but because of an international recognition that juveniles merit special legal protection in light of their status as children. Although there are a number of international human rights instruments that contain references to the prohibition of juvenile death penalty, the principal laws relied upon by those who challenges the US practice are the followings.

\subsection{Universal Declaration of Human Rights}

The repercussions of World War II sparked the first international treaty on human rights: The Universal Declaration of Human Rights adopted by the United Nations General Assembly in 1948. This declaration was intended as an absolute right to life proclamation (Universal Declaration of Human Rights, Dec. 1948) Article 5 of the Declaration states,

“No one shall be subjected to torture or to cruel, inhuman or degrading treatment or punishment”.

In the years following the declaration, the United Nations realized its goal to wipe out the death penalty in its entirety was too progressive for the international community; instead, its later treaties focused on protecting the weaker in society including, pregnant women, juveniles, and elderly. The Universal Declaration of Human Rights, however, was one of the first treaties on human rights and has served as the precedent for most international commissions and treaties including, the Inter-American Commission on Human Rights, later adopted as the American Convention on Human Rights ${ }^{1}$, the African [Banjul] Charter on Human and People's Rights ${ }^{2}$ and the European Convention for the Protection of Human Rights ${ }^{3}$.

\subsection{International Covenant on Civil and Political Rights (ICCPR)}

Following the Universal Declaration of Human Rights, the International Covenant on Civil and Political Rights (ICCPR), contains a wide-ranging list of individual rights, is considered by many to the "cornerstone of modern international human rights law” (William Schabas, 1995) With respect to juvenile offenders, Article 6(5) of the treaty states that:

\footnotetext{
${ }^{1}$ American Convention on Human Rights Stating under Article 5, "No one shall be subjected to torture or to cruel, inhuman, or degrading punishment or treatment ... capital punishment shall not be imposed upon person who, at the time the crime was committed, were under 18 years of age or over 70 years; nor shall be applied to pregnant women Art. 4(5)”.

${ }^{2}$ African [Banjul] Charter on Human and People's Rights (stating under Article 5, "all forms of exploitation and degradation of man, particularly slavery, slave trade, torture, cruel, inhuman or degrading punishment and treatment shall be prohibited").

${ }^{3}$ European Convention for the Protection of Human Rights (stating in Article 3, "no one shall be subjected to torture of inhuman treatment or punishment”).
} 
"Sentence of death shall not be imposed for crimes committed by persons below eighteen years of age and shall not be carried out on pregnant women."

In December 1989, the UN General Assembly adopted the Second Optional Protocol to the ICCPR. That document called on States to abolish the death penalty entirely, acknowledging the trend toward worldwide abolition of the death penalty for all persons and all purposes ${ }^{5}$.

The ICCPR came into force in the United States on September 8, $1992^{6}$. The US State Department praised it as "the most complete and authoritative articulation of international human rights law that has emerged in the years following World War II" ". However the United States ratified the treaty with several reservations, understandings and declarations, which is called RUDS. The US Reservation to Article 6 is quite broad and reads:

The United States reserves the right, subject to its Constitutional constraints, to impose capital punishment on any person (other than a pregnant woman) duly convicted under existing or future laws permitting the imposition of capital punishment, including such punishment for crimes committed by persons below eighteen years of age. ${ }^{8}$

However, the United Nations Human Rights Committee found that the reservation went against "peremptory norms" and was completely "incompatible with the object and purpose" of the treaty (Dorsen, 1997). This argument is based on the Vienna Convention on the Law of Treaties, a treaty that regulates the standards for treaty ratification, interpretation and termination (Bradley \& Goldsmith, 2000). Although the United States has not ratified the convention, Executive Branch officials have stated that they accept at least much of the convention as reflecting binding customary international law (Curtis B.). The ICCPR's Human Rights Committee in 1994 concluded that stated reservations that violate the object and purpose of the ICCPR should generally be considered severable, "in the sense that the covenant will be operative for the reserving party without benefit of the reservation” (Human Rights Committee, General Comment 24, 1994). The committee also expressed the view that "it necessary fails to the committee to determine whether a specific reservation is compatible with the object and purpose of the covenant ${ }^{9}$. Therefore, as per the above comments the US juvenile death penalty reservation is invalid, and that the proper remedy for this invalidation is to enforce the ICCPR against the United State as if it had never included the reservation.

\subsection{Convention on the Rights of the Child}

The United Nations Convention on the Rights of the Child(CRC) provides a comprehensive articulation of the civil, political, and social rights of children and endeavors to promote the basic needs of children as fundamental human rights (Calciano, 1992) Article 37(a) states that;

"Neither capital punishment nor life imprisonment without the possibility of release shall be imposed for offenses committed by persons below eighteen years of age." (Convention on the Rights of the Child, 1989)

Article 51(2) seeks to guarantee this protection by preventing a state from making a reservation to the CRC which is inconsistent with the object and purpose of the Convention. Therefore, according to Article 51(2), a state may not simultaneously ratify the CRC and refuse to exempt juveniles from capital punishment because the exclusion of minors from the death sentence is clearly a vital objective of the agreement, as evidenced by Article 37(a). Every country in the world has ratified this treaty, except the US and Somalia. The United States signed the convention in 1995 with a renewed reservation exempting itself from adherence to the juvenile death penalty ban, but the Senate is concerned with the conflict between the death penalty practice of many states in the US regarding juveniles and Article 37(a). So far, though the US does not ratify the CRC, in August 2000, the UN Sub-Commission on the Promotion and Protection of Human Rights reiterated that the execution of juveniles violates customary international law.

\footnotetext{
${ }^{4}$ International Covenant on Civil and Political Rights, 999 UNTS 171 (1976), at Art. 6

${ }^{5}$ See the Second Optional Protocol to the International Covenant on Civil and Political Rights, Aiming at Abolition of the Death Penalty U.N Doc. A/44/49, (1991)

${ }^{6}$ The United States Deposited Its Ratification With The United Nations in 1992. See United Nations, Multilateral Treaties Deposited With The Secretary General: Status As At 31 Dec. 1999, At 134.

${ }^{7}$ Id.

${ }^{8}$ US Reservation to Article 6 of the ICCPR, UN Doc. ST/LEG/SER.E/13, p. 175.

${ }^{9}$ Id.
} 


\subsection{The Fourth Geneva Convention}

The Geneva Convention Relative to the Protection of Civilian Persons in Time of War explicitly prohibits imposition of the death penalty on "protected person" (civilians and other non-combatants) who are under eighteen years of age at the time of their offense ${ }^{10}$. This is the only other treaty that the United States has rarified in 1955 and did not make a reservation to the convention's juvenile death penalty clause ${ }^{11}$.

Therefore, as per the Fourth Geneva Convention, it is understandable that America has agreed not to apply the death penalty to any civilian juvenile offenders in occupied territories in a time of war. However, her refusal to provide the same protection to juvenile offenders on its own territory during peacetime as far as the writer concerned is irrational and irresponsible.

\subsection{American Convention on Human Rights}

The American Convention on Human Rights articulates the rights and freedoms enjoyed by citizens of the member states of the Organization of American States (OAS) ${ }^{12}$. Twenty-five countries of the western hemisphere have ratified this treaty, which states "Capital punishment shall not be imposed upon persons who, at the time the crime was committed, were under 18 years of age" ${ }^{\text {"13 }}$. In addition, Article 27 secures this legal safeguard for children by preventing a state from derogating from Article 4(5).

Even though the United States has signed but not ratified the convention, as a signatory to the convention, it should, in principle, be barred from acting in contravention of its terms (Arnett, 1988). Under international law, a country is expected to abide by a treaty it has signed, even as it awaits final ratification ${ }^{14}$.

\subsection{The Doctrine of Jus Cogens and Customary International Law}

Here, the writer argues that the practice of execution of juvenile delinquents by United States in dated times was/is against the law, not only because the above major international human rights laws prohibit the execution of persons who are under eighteen years of age at the commission of the crime, but the US practice is void for the following stronger reasons specifically in relation to Article 6(5) of the ICCPR.

First, Article 19 of the Vienna Convention on the Law of Treaties states that a party "may, when signing, ratifying, accepting, approving, or acceding to a treaty, formulate a reservation unless...the reservation is incompatible with the object and purpose of the treaty"15. Thus, the main purpose of ICCPR is to protect the rights of citizens with a given state's boundaries. The covenant provides the right to life as a fundamental human right and it sets out in unambiguous language regarding the treatment of juvenile offenders in Article 4, which provides no derogation is allowed from Article 6, even in times of public emergency. So the writer argues that the United States reservation to Article 6 (5) clearly contradict the object and purpose of that provision in particular and the entire treaty in general that, the US was in infringement and would be in violation of the treaty if it maintained the practice.

Second, the United States is still bound by norms of jus cogens, because these norms are "based on natural law propositions applicable to all legal systems, all persons, or the system of international law” (Jonathan, 1993). The Vienna Convention on the Law of Treaties, defines a jus cogensas, "a norm accepted and recognition by the international community of States as a while as a norm from which no derogation is permitted and which can be modified only by a subsequent norm of general international law having the same character".

Here, the abolition of the juvenile death penalty so widespread all over the world except very few countries that, the writer argues that the abolition of the juvenile death penalty acquired the status of jus cogens, the United States reservation to Article 6(5) of the International Covenant on Civil and Political Rights is invalid.

Third, which is the most persuasive argument as far as the writer concerned, the abolition of the juvenile

\footnotetext{
${ }^{10}$ See The Geneva Convention Relative to the Protection of Civilian Persons in Time of War, Aug. 12, 1949, 6 U.S.T. 3516, 75 U.N.T.S. 287 art. 68 .

${ }^{11}$ The United States did not attach a reservation concerning the juvenile death penalty, however, attached a reservation to its ratification of the treaty declining to agree to the convention.

${ }^{12}$ Charter of the Organization of American States, Signed Apr. 30, 1948.

${ }^{13}$ American Convention on Human Rights, Article 4(5).

${ }^{14}$ See International Commission of Jurists, Administration of the Death Penalty in the United States 33 (June 1996) at www.muse.jhu.edu/journals/human_rights.../19.1int_comm_of_jurists.html

${ }^{15}$ See Vienna Convention on the Law of Treaties, opened for signature may 23, 1969, art 19, 1155 U.N.T.S. 331, 352, 8 I.L.M 679, 698 at www.sitemaker.umich.edu/.../vienna_convention_on_the_law_of_treaties.pdf
} 
death penalty attained the status of customary international law particularly through the ICCPR and CRC that, the United States still bound by it. In order to be considered customary international law, a provision must be: state practice-evidenced by long-term, widespread compliance by many states; and opinion juris-states must believe that compliance with standard is not merely desired, but mandatory and required by international law (Loschin, 1996). Thus, the first element of customary international law doctrine, state practice is easily established by the fact that almost every nation in the world has ratified the CRC and ICCPR, and abolished punishment for juvenile delinquents; however, the only States not to ratify are Somalia and the United States. A more persuasive argument for establishing the second element opinion juris involves the sentiments expressed during the preparation of treaties such as ICCPR. After all, "what is the source of the nations" disinclination to execute juvenile offender other than a shared sense of the moral reprehensiveness of the practice? (Nanda, 1993). That is, treaties themselves clearly enunciate the intentions of the drafter-the countries of the world-that their treaty provisions be unanimously applied international law (De La Vega \& Jennifer, 1998).

Therefore, the writer argues that since customary international law prohibits the execution of juvenile delinquents, it imposes a legal obligation on the United States to eliminate this practice even if the United States is not ratified the Convention on the Rights of the Child, the American Convention on Human Rights and made reservation to Article 6(5) of the International Covenant On Civil and Political Rights.

\section{Recent Jurisprudence against the Execution of Juvenile Delinquents in the US Courts}

\subsection{The Eighth Amendment of US Constitution}

The primary standard for interpreting the constitutionality of death penalty cases in the United States is the clause in the $8^{\text {th }}$ Amendment to the Constitution. The Eighth Amendment of the US Constitution provides that "excessive bail shall not be required, nor excessive fines imposed, nor cruel and unusual punishments inflicted" ". Early interpretations of the clause dating back to 1879 understood the terms "cruel and unusual punishments" construed narrowly to prohibit only barbarous forms of punishment such as torture, the Eighth Amendment now prohibits sentences that are either contrary to the evolving standards of decency in maturing society, or disproportionate to the commission of a defendant's underlying offense (Trop v. Dulles, 1958).

As mentioned in the beginning if this essay, the establishment in 1899 of the US's first juvenile court reflected a new understanding of the limitations of children and adolescents. Due to children's underdeveloped maturity, poor rationality, and their adult potential, reviewing courts traditionally have given children special consideration when determining whether their execution violate the constitutional prohibition against cruel and unusual punishment in Eighth Amendment. Concerning this situation let us see two prominent cases decided in the US Supreme Court.

\subsection{Thompson v. Oklahoma}

William Thompson was fifteen years old when, in concert with three older individuals, he participated in the beating and murder of his former brother-in-law (Thompson v. Oklahoma, 1988). Thompson was sentenced to death for his role and, after the Oklahoma court of criminal appeals affirmed, the Supreme Court granted certiorari to consider whether a death sentence is cruel and unusual punishment for a fifteen-year-old who participated in a murder.

In holding that "the Eighth Amendment prohibits the execution of a person who was under 16 years of age at the time of his or her offense," a court plurality considered whether "contemporary standards of decency" allowed a juvenile to act with the degree of culpability that justifies capital punishment. The plurality noted that of the eighteen states that have set an age in their death penalty statutes, all mandate, at a minimum, that the defendant have attained at least the age of sixteen at the time of his commission of the offense. The plurality also recognized that the practice of other nations may inform the analysis of societal standards of decency.

The court first considered pertinent legislative enactments and observed that Oklahoma, like several other states, prohibits minors from voting, sitting on a jury, marrying without parental consent, and purchasing alcohol or cigarettes. Additionally, Oklahoma retains a juvenile-justice system in which most offenders under age eighteen are not held criminally responsible for their actions.

\footnotetext{
${ }^{16}$ US Constitution, Amendment. VIII. Available https://www.law.cornell.edu/constitution/eighth_amendment
} 
Taken together, the court reasoned, "All of this legislation is consistent with the experience of mankind, as well as the long history of our law, that the normal 15-year-old is not prepared to assume the full responsibilities of an adult”. The Court stated:

The conclusion that it would offend civilized standards of decency to execute a person who was less than 16 years old at the time of his or her offense is consistent with the views that have been expressed by respected professional organizations, by other nations that share our Anglo-American heritage, and by the leading members of the Western European community... Although the death penalty has not been entirely abolished in the United Kingdom or New Zealand (it has been abolished in Australia, except in the State of New South Wales, where it is available for treason and piracy), in neither of those countries may a juvenile be executed. The death penalty has been abolished in West Germany, France, Portugal, The Netherlands, and all of the Scandinavian countries, and is available only for exceptional crimes such as treason in Canada, Italy, Spain, and Switzerland. Juvenile executions are also prohibited in the Soviet Union.

Finally, the Court exercised its own judgment to conclude that sentencing Thompson to death violated the Eighth Amendment. In doing so, the court emphasized that a juvenile's criminal behavior should not be measured using adult standards. Unlike adults, juveniles-including adolescents show less maturity and responsibility.

\subsection{Roper v. Simmons}

At the age of seventeen, respondent Christopher Simmons entered the victim's home with an accomplice after dark and used duct tape to cover the victim's eyes and mouth and bind her hands (Roper v. Simmons, 2005). They then put the victim in her own minivan and drove her to a state park where they walked her to a railroad trestle and threw her from the bridge. Within days, authorities received information that led to respondent's arrest, confession, and videotaped reenactment of the crime. Following a jury trial, respondent was found guilty of first-degree murder and sentenced to death. However, the court emphasized that the well-documented immaturity of juveniles makes them less culpable for their crimes and less easily deterred by the threat of punishment. The court also stressed the unformed characters of juveniles, which raised the possibility of reform and even forgiveness for their crimes neither reform nor forgiveness is possible with a final and irrevocable punishment such as execution, because ending a juvenile's life prevents him from attaining "a mature understanding of his own humanity". Finally, the court emphasized "evolving standards of decency" as evidenced by a number of state legislatures prohibiting the execution of juveniles and the increasingly rare execution of juveniles in states where capital sentences are permissible. For these reasons, the court held that death by execution, when applied to juveniles, is cruel and unusual punishment and violates the Eighth Amendment to the Constitution of the United States. Thus, even if US was executed juvenile delinquents for over three centuries, now it came into compliance with international norms by banning the death penalty as applied to juveniles in the above landmark Supreme Court cases.

\section{Conclusions}

A juvenile justice system separate from the adult criminal justice system was established in the United States in Cook County, Illinois 1899. Prior to this, the same criminal justice system was used for both children and adults. A primary purpose of the juvenile justice system was to provide treatment, rehabilitative services, not punishment.

The first recognized United States execution of a juvenile delinquent occurred in 1642, in Plymouth Colony, Massachusetts. The United States is considered to be deficient when it comes to certain human rights practices, namely juvenile executions because beginning from the first execution until recently, the US executed juveniles for crimes committed by persons who are under eighteen years of age at the commission of the crime.

There are a number of international human rights instruments that contain references to the prohibition of juvenile death penalty, among this Article 5 of the UDHR provided as an absolute right to life, Article 6(5) of the International Covenant on Civil and Political Rights, Article 37(a) of the Convention on the Rights of the Child and Article 4(5) of the American Convention on Human Rights, provides prohibition of death penalty for persons while below the age of 18 .

The United States ratified the ICCPR with reservation to Article 6, however, the United Nations Human Rights Committee found that the reservation went against peremptory norms and was completely incompatible 
with the object and purpose of the treaty.

The United States has not yet ratified both the American Convention on Human Rights and the Convention on the Rights of the Child, however, the prohibition of juvenile death penalty attained the status of customary international law and jus cognes that, it imposes a legal obligation on the United States that, the practice of execution of juvenile delinquents by United States in dated times was/is against the law even if the United States has not ratified these conventions. In recent times the United States courts used the Eighth Amendment of the US constitution that provides the terms cruel and unusual punishments as a primary standard for interpreting the constitutionality of death penalty cases. The US court for cases Thompson v. Oklahoma and Roper v. Simmons decided that, death by execution, when applied to juveniles, is cruel and unusual punishment and violates the Eighth Amendment to the constitution of the United States.

\section{References}

Arnett, L. K. (1988). Death at an Early Age: International Law Arguments against the Death Penalty for Juveniles. 57 U. Cin. L. Re v. 245, 246

Arnett, L. K. (1988). Death at an Early Age: International Law Arguments against the Death Penalty for Juveniles. University of Cincinnati Law Review, 57, 245-265.

Banks, J. M. (1999). Do Evolving Standards of Decency under Eighth Amendment Jurisprudence Render Capital Punishment Inapposite for Juvenile Offenders? South Dakota Law Review, 48, 327-331.

Bradley, C. A., \& Goldsmith, J. L. (2000). Treaties, Human Rights, and Conditional Consent. University of Pennsylvania Law Review, 149, 339-404. http://dx.doi.org/10.2307/3312731

Calciano, E. M. (1992). United Nations Convention on the Rights of the Child: Will It Help Children in the United States? Hastings International and Comparative Law Review, 15, 515-534.

Cothern, L. (2003). Juveniles and the Death Penalty. www.ncjrs.gov/pdffiles1/ojjdp/184748.pdf

De La Vega, C., \& Jennifer, B. (1998). Can a United States Treaty Reservation Provide a Sanctuary for the Juvenile Death Penalty?

Dorsen, N. (1997). Civil Liberties, National Security and Human Rights Treaties: A Snapshot in Context. UC Davis Journal of International Law and Policy, 3, 153.

Harvard University (2005). Prevention of Juvenile Crime in the United States and Japan Program on US-Japan Relations 61 Kirkland Street Cambridge.

Jonathan, C. (1993). Universal International Law. American Journal of International Law, 87, 529-541. http://dx.doi.org/10.2307/2203615

Koestler, A. (1957). Reflections on Hanging. www.justicestudies.com/cd_extras/cdExtra115.swf

Lawrence, R. (1998). School Crime and Juvenile Justice. New York: Oxford University Press.

Loschin, L. (1996). The Persistent Objector and Customary Human Rights Law: A Proposed Analytical Framework. UC Davis Journal of International Law and Policy, 3, 148-150.

Miles v. State, 54 So. 946, 946. www.in.gov/judiciary/opinions/pdf/06300801per.pdf

Nanda, V. (1993). The United States Reservation to the Ban on the Death Penalty for Juvenile Offenders: An Appraisal under the International Covenant on Civil and Political Rights. DePaul Law Review, 42, 1334.

Platt, A. \& Diamond, B. L. (1966). The Origins of the "Right and Wrong” Test of Criminal Responsibility and Its Subsequent Development in the United States: An Historical Survey, 54 Cal. L. Rev.

Roper v. Simmons (2005). 543 U.S. www.tumca.org/aug09/Roper\%20v.\%20Simmons,\%20543\%20U.S.pdf

Snyder, H. N., \& Sickmund, M. (2006). Juvenile Offenders and Victims: National Report Office of Juvenile Justice and Delinquency Prevention.

Spring, M. E. (1998). Extended Jurisdiction Juvenile Prosecution: A New Approach to the Problem of Juvenile Delinquency in Illinois. The John Marshall Law Review, 31, 1351-1384.

Streib, V. L. (2004), The Juvenile Death Penalty Today: Death Sentences and Executions For Juvenile Crimes. Ohio Northern University

Thompson v. Oklahoma (1988). 487 U.S. 815, 823. www.law.cornell.edu/supct/.../USSC_CR_0487_0815_ZS.html

Torbet, P. et al. (1996). State Responses to Serious and Violent Juvenile Crime. Washington DC: Office of Juvenile Justice and Delinquency Prevention.

Trop v. Dulles (1958). 356 U.S. 86, 101 and Ewing v. California, (2003). 538 U.S. 11, 23-24. 
Tuell, J. A. (1998). Juvenile Offenders and the Death Penalty, Is Justice Served? https://www.ncjrs.gov/App/publications/abstract.aspx?ID=199835

Yeckel, J. F. (1997). Violent Juvenile Offenders: Rethinking Federal Intervention in Juvenile Justice. http://openscholarship.wustl.edu/cgi/viewcontent.cgi?article=1067\&context=law_urbanlaw

\section{Laws}

1) Universal Declaration of Human Rights.

2) International Covenant on Civil and Political Rights.

3) Convention on the Rights of the Child.

4) The fourth Geneva Convention.

5) American Convention on Human Rights.

6) African [Banjul] Charter on Human and People's Rights.

7) European Convention for the Protection of Human Rights.

8) Second Optional Protocol to the International Covenant on Civil and Political Rights.

9) Vienna Convention on the Law of Treaties.

10) U.S. Constitution, Amendment. VIII.

11) Geneva Convention Relative to the Protection of Civilian Persons in Time of War. 